\title{
Lymphocytes bearing Fcy receptors in rheumatoid arthritis. III. Immunoregulatory function associated with Facb rosette-forming cells
}

\author{
LESLEY-JANE EALES, * N J GOULDING, N D HALL, \\ VIVIENNE R WINROW, $†$ AND I M HUNNEYBALL
}

From the ARC Research Group, Royal National Hospital for Rheumatic Diseases, Bath, the Pharmacology Group, University of Bath, and $\ddagger$ the Boots Company PLC, Nottingham

SUMMARY A subpopulation of mononuclear cells (PBMNC) that express Fc receptors with specio ficity for the $\mathrm{C} \gamma 2$ region of IgG may be detected by rosette formation with calf erythrocytes coated with the Facb fragment of rabbit IgG. These Facb- $R^{+}$cells are found in increased numbers in the peripheral blood of patients with rheumatoid arthritis (RA). Studies have been carried out to? identify the functional properties of these cells in healthy and rheumatoid subjects. Facb- $\mathrm{R}^{+}$cell were shown to lack both natural killer and antibody-dependent cytotoxic activity. Depletion of Facb- $\mathrm{R}^{+}$cells from both healthy and rheumatoid PBMNC resulted in a marked suppression ofo pokeweed mitogen (PWM) stimulated IgG synthesis but had no effect on $\mathrm{T}$ cell proliferation induced by phytohaemagglutinin, concanavalin A, or PWM. The addition of Facb fragments tof PBMNC cultures also caused inhibition of PWM-driven IgG production. In this assay rheumatoid PBMNC were significantly less sensitive to Facb-mediated suppression than healthy control cells Our results suggest that Facb- $\mathrm{R}^{+}$cells are involved in the antibody-mediated feedback regulation of immunoglobulin synthesis and that this mechanism is impaired in patients with RA.

Key words: rheumatoid arthritis, antibody synthesis, feedback inhibition, Fc receptor.

The accompanying paper $^{1}$ describes the surface marker expression of a subpopulation of Fcy receptor (FCR)-bearing mononuclear cells which may be identified by their ability to form rosettes with Facbcoated calf red blood cells (CRBC). These Facb- $\mathbf{R}^{+}$ cells have been found in increased numbers in the peripheral blood of patients with rheumatoid arthritis. ${ }^{2}$ Facb- $\mathrm{R}^{+}$cells lack conventional markers of $\mathrm{T}$ and $\mathrm{B}$ lymphocytes but express certain antigens, including OKM1 and HLA-DR, which may also be detected on monocytes. ${ }^{1}$ The pattern of surface phenotype observed for Facb- $\mathrm{R}^{+}$cells is therefore similar to that described for $\mathrm{L}$ cells, ${ }^{3-5}$ although

Accepted for publication 5 July 1984 .

Current addresses: *Department of Immunology, Wright-Fleming Institute, St Mary's Hospital Medical School, London W2. †Bone and Joint Research Unit, London Hospital Medical College, London E1.

Correspondence to Dr N D Hall, Royal National Hospital for Rheumatic Diseases, Upper Borough Walls, Bath BA1 1RL.
Facb- $\mathrm{R}^{+}$cells are clearly associated with a monocytig lineage.

A number of functions have been ascribed to this class of non- $\mathrm{T}$, non-B, $\mathrm{FcR}^{+}$cells. These include both natural killing and antibody-dependent cellulaळ cytotoxicity ${ }^{4-8}$ and regulatory effects on lymphocyte activity. The latter include the stimulation of lymo phocyte proliferation ${ }^{5910}$ and both enhancing and suppressive effects on antibody production. ${ }^{5}$ In thio report the properties of Facb- $\mathrm{R}^{+}$cells from botho healthy individuals and rheumatoid patients haves been investigated in a variety of assays of lymphocyteg function.

\section{Materials and methods}

Patient selection and mononuclear cell preparation Mononuclear cells (PBMNC) were prepared fror heparinised peripheral blood samples taken, wito informed consent, from healthy volunteers and from patients with classical or definite rheumatoid arthe 
ritis, as described in the accompanying paper. ${ }^{1}$ PBMNC were separated by density flotation over Ficoll-Paque (Pharmacia). ${ }^{11}$

Preparation and use of Facb fragment. Facb fragments were prepared by plasmin digestion of a purified $\mathrm{IgG}$ fraction of rabbit anti-CRBC, and PBMNC expressing surface receptors for the Facb portion of $\mathrm{IgG}$ were detected by a rosette assay as previously described. ${ }^{2}$ In some experiments PBMNC were depleted of Facb- $\mathrm{R}^{+}$cells as follows: PBMNC were incubated at a final concentration of $1 \times 10^{6} / \mathrm{ml}$ with an equal volume of $1 \% \mathrm{v} / \mathrm{v}$ Facb-sensitised CRBC on ice for 1 hour. Rosetted cells were separated from unrosetted cells by density flotation over Ficoll-Paque. Unrosetted cells were considered Facb-depleted only after testing by re-rosetting with Facb-sensitised CRBC. As a control total PBMNC were sham-depleted with non-sensitised CRBC.

Lymphocyte proliferation. The effects of addition of Facb fragment and of depletion of Facb- $\mathrm{R}^{+}$cells on proliferative responses of PBMNC to certain mitogens were examined. Cells were cultured in 200 $\mu l$ aliquots of RPMI 1640 (Gibco) at a concentration of $5 \times 10^{5} / \mathrm{ml}$. The culture medium contained $10 \%$ heat-inactivated fetal calf serum (Gibco), $4 \mathrm{mM}$ glutamine, and $100 \mathrm{U} / \mathrm{ml}$ penicillin-streptomycin (Gibco). Quadruplicate cultures of PBMNC were aliquoted into round-bottomed microtitre plates (Nunc). In order to achieve optimal mitogenic stimulation three separate dilutions of concanavalin $\mathrm{A}$ (con A, Sigma), phytohaemagglutinin (PHA, Gibco), and pokeweed mitogen (PWM, Gibco) were used. Cell cultures were incubated for 68 hours at $37^{\circ} \mathrm{C}$ in humidified air containing $5 \% \mathrm{CO}_{2}$. Subsequently each culture was supplemented with $0.5 \mu \mathrm{Ci}$ ${ }^{3} \mathrm{H}$-thymidine (specific activity $5 \mathrm{Ci} / \mathrm{mmol}$, Amersham). After a further 4 hours at $37^{\circ} \mathrm{C}$ the cells were harvested and the uptake of radioisotope measured by liquid scintillation spectrometry.

$P W M$-driven immunoglobulin synthesis. Duplicate cultures of PBMNC $\left(1 \times 10^{6} / \mathrm{ml}\right.$ in RPMI 1640 supplemented as above) were set up in sterile culture plates (Nunc). Cultures (volume $1 \mathrm{ml}$ ) contained either total PBMNC or PBMNC depleted of Facb- $\mathbf{R}^{+}$ cells by rosetting. Cells received either no mitogen or a 1:200 dilution of PWM (Gibco) in calcium- and magnesium-free salt solution (CMFSS). Cells also received varying amounts of rabbit Facb fragment $(0-15 \mu \mathrm{g} / \mathrm{ml})$. After incubation for seven days at $37^{\circ} \mathrm{C}$ the supernatants were harvested and stored at $-70^{\circ} \mathrm{C}$ until analysed for $\mathrm{IgG}$ content.

Enzyme-linked immunosorbent assay (ELISA). Polystyrene Gilford system cuvettes were coated with sheep polyvalent antihuman immunoglobulins (Sigma). After washing, doubling dilutions of either test supernatants or standard IgG preparations were added. After one hour at $37^{\circ} \mathrm{C}$ and a further washing step an optimum dilution of rabbit antihuman IgG conjugated to alkaline phosphatase (Sigma) was added. A further incubation and final wash cycle were followed by addition of developing substrate (disodium $p$-nitrophenol phosphate). Absorbance readings were taken from each well at $405 \mathrm{~nm}$ (Gilford EIA Manual Reader) and concentrations of IgG in the supernatants estimated from the standard curve.

Cytotoxicity assays. Natural killer (NK) assays were performed on total PBMNC cultures and those depleted of Facb- $\mathrm{R}^{+}$cells. The method used was a variation of that used by Pape et al. ${ }^{12}$ Cells from the erythroleukaemic line K562 were maintained in RPMI 1640 medium supplemented as above. Washed cells $\left(3 \times 10^{6} / \mathrm{ml}\right)$ were labelled with ${ }^{51} \mathrm{Cr}$ by incubation with $100 \dot{\mu} \mathrm{Ci} \mathrm{Na}{ }^{51} \mathrm{CrO}_{4}$ (Amersham) for one hour at $37^{\circ} \mathrm{C}$ and washed three times before use as targets. The assays were performed in plastic LP3 tubes (Luckham). Target cells were adjusted to a concentration of $2 \times 10^{4} / \mathrm{ml}$ and $250 \mu$ added to an equal volume of PBMNC at a final concentration of $1 \cdot 2 \times 10^{6}$ or $6 \times 10^{5}$ cells $/ \mathrm{ml}$ giving a lymphocyte:target ratio of either $60: 1$ or $30: 1$. After incubation for 16 hours at $37^{\circ} \mathrm{C}$ the cells were sedimented by centrifugation at $200 \mathrm{~g}$ for 10 minutes. Radioactivity present in the pellet and supernatant was measured in a gamma-counter (LKB Wallac) and the amount of specific cytotoxicity expressed as a percentage of ${ }^{51} \mathrm{Cr}$ released from the target cells corrected for spontaneous release from K562 cells cultured in medium alone.

Antibody-dependent cytotoxicity (K cell activity) of PBMNC and Facb- $\mathrm{R}^{+}$depleted cells was investigated using the method of Panayi and Corrigall. ${ }^{13}$ IgG-coated Chang cells labelled with ${ }^{51} \mathrm{Cr}$ as above were used as targets.

\section{Results}

Immunoglobulin synthesis. When increasing amounts of Facb fragment were added to PWMstimulated PBMNC cultures, a dose-dependent suppression of $\mathrm{IgG}$ production resulted (Fig. 1). The data demonstrate that this suppression was significantly less marked in cultures from patients with RA than in cultures from age and sex-matched controls $(p<0 \cdot 01$, Mann-Whitney $U$ test). Baseline levels of IgG production, i.e., responses to PWM without addition of Facb fragment, were lower in the rheumatoid cell cultures $(933 \pm 1109 \mathrm{ng} / \mathrm{ml})$ than in healthy control cultures $(1236 \pm 1230 \mathrm{ng} / \mathrm{ml})$, but this difference was not statistically significant in these experiments. Responses to Facb fragment were very similar in all control cultures tested, but cells from 


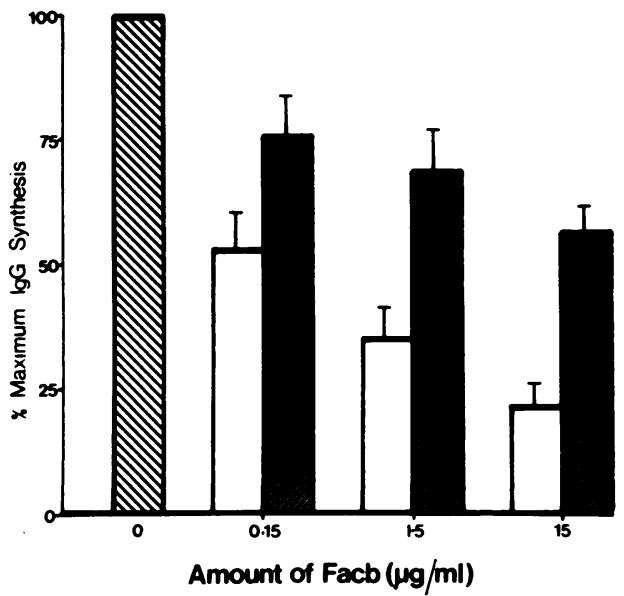

two of the 10 rhe umatoid patients failed to suppress antibody production irrespective of the dose of Facb fragment added.

The possible mechanisms underlying the Facbmediated suppression of antibody production were studied by investigating the effect of Facb- $\mathrm{R}^{+}$cell depletion on PWM-stimulated IgG synthesis. As illustrated in Table 1, this procedure led to a marked inhibition of IgG production by both healthy and rheumatoid PBMNC. The addition of Facb fragment to cultures of Facb- $\mathrm{R}^{+}$depleted PBMNC had no further effect. The low levels of IgG synthesis by these cells were not caused by a loss of monocytes, since significant numbers of these cells remained in the preparation as identified by non-specific esterase staining.

Lymphocyte proliferation. The depletion of Facb- $\mathrm{R}^{+}$cells from PBMNC cultures had no signifi-

Table 1 The effects of Facb-R $R^{+}$cell depletion and the addition of Facb fragments on $P W M$-driven $\operatorname{IgG}$ production by $P B M N C$

\begin{tabular}{|c|c|c|}
\hline \multirow[b]{2}{*}{ Source of PBMNC } & \multicolumn{2}{|c|}{ \% PWM-driven IgG production } \\
\hline & $-F a c b$ & $+F a c b$ \\
\hline \multicolumn{3}{|c|}{ Healthy controls $(n=6)$} \\
\hline Non-depleted & 100 & $32 \pm 9$ \\
\hline Facb- $\mathbf{R}^{+}$depleted & $46 \pm 19$ & $52 \pm 18$ \\
\hline \multicolumn{3}{|l|}{ RA patients $(n=5)$} \\
\hline Non-depleted & 100 & $64 \pm 9$ \\
\hline Facb- $\mathbf{R}^{+}$depleted & $31 \pm 16$ & $28 \pm 14$ \\
\hline
\end{tabular}

Results are presented as the mean \pm SEM IgG production expressed as a percentage of the response in non-depleted cultures $(=100 \%)$. Rabbit Facb fragment was added at a final concentration of 1.5 $\mu \mathrm{g} / \mathrm{ml}$.

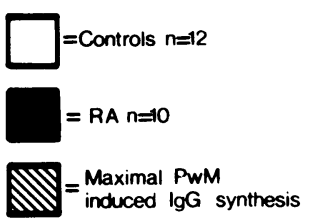

Fig. 1 The effect of rabbit Fac $b \frac{\overline{\mathrm{C}}}{\bar{\varnothing}}$ fragment on PWM-stimulated Ig synthesis. Results are expressed iT percentage terms (mean $\pm S E M$ ) relative to $\mathrm{Ig} G$ production in PWM-stimulated cultures without addition of Facb $(=100 \%)$. Rheumatoid PBMNC are significantly less sensitive than healthy control cells to inhibition Facb at 1.5 and $15 \mu \mathrm{g} / \mathrm{ml}(p<0 \cdot 0$. Mann-Whitney $U$ test).

cant effect on lymphocyte proliferation stimulated be either con A, PHA, or PWM as measured by ${ }^{3} \mathrm{~K}$ thymidine incorporation into DNA (Table 2). ThE proliferative response of PBMNC to the threg mitogens was also unaffected by the addition of Fack fragments to the cultures (data not shown).

Cellular cytotoxicity. When PBMNC were depleted of Facb- $\mathrm{R}^{+}$cells, there was no reduction o NK activity measured at two separate lymphoo cyte:target cell ratios (Table 3 ). The mean spontå neous release of ${ }^{51} \mathrm{Cr}$ was $23 \cdot 3 \pm 1 \cdot 3 \%$. K cell activit $\vec{\Phi}$ against Chang cells was also not significantly altere on depletion of Facb-R $\mathrm{R}^{+}$cells (Fig. 2) but was abro gated by the removal of all $\mathrm{FcR}^{+}(\mathrm{EA}$ rosetteforming) cells.

Table 2 Effect of Facb- $R^{+}$cell depletion on mitogen-induced lymphocyte proliferation

\begin{tabular}{|c|c|c|c|c|}
\hline \multirow[b]{2}{*}{ Mitogen } & & \multicolumn{2}{|c|}{$\begin{array}{l}{ }^{3} H \text {-thymidine incorporation }(c p m) \\
\text { by } P B M N C\end{array}$} & \multirow{2}{*}{$\frac{\text { D }}{\text { d }}$} \\
\hline & & Non-depleted & Facb $-R^{+}$depleted & \\
\hline Con A & $\begin{array}{r}10 \mu \mathrm{g} / \mathrm{ml} \\
50 \mu \mathrm{g} / \mathrm{ml} \\
100 \mu \mathrm{g} / \mathrm{ml}\end{array}$ & $\begin{array}{l}3207 \pm 1047 \\
3915 \pm 1357 \\
2966 \pm 1391\end{array}$ & $\begin{array}{l}3084 \pm 1551 \\
4159 \pm 963 \\
3451 \pm 1315\end{array}$ & ల్ \\
\hline PHA & $\begin{array}{l}0 \cdot 2 \mu \mathrm{g} / \mathrm{ml} \\
1 \mu \mathrm{g} / \mathrm{ml} \\
5 \mu \mathrm{g} / \mathrm{ml}\end{array}$ & $\begin{array}{l}2488 \pm 453 \\
3673 \pm 946 \\
2451 \pm 554\end{array}$ & $\begin{array}{l}2371 \pm 598 \\
4453 \pm 1546 \\
3054 \pm 1280\end{array}$ & $\frac{\mathscr{C}}{\text { D }}$ \\
\hline PWM & $\begin{array}{l}1: 2000 \\
1: 400 \\
1: 40\end{array}$ & $\begin{array}{l}2645 \pm 1458 \\
4142 \pm 2110 \\
2936 \pm 1376\end{array}$ & $\begin{array}{c}807 \pm 688 \\
2880 \pm 1334 \\
2196 \pm 662\end{array}$ & $\frac{\text { Oे }}{\text { (D) }}$ \\
\hline
\end{tabular}

Results are expressed as ${ }^{3} \mathrm{H}$-thymidine incorporation $(\mathrm{cpm} / 10$ PBMNC) and are the mean \pm SEM of six experiments using rheumatoid cells. Similar data (not shown) were obtained in eig迎 experiments using healthy control PBMNC. 
Table 3 The effect of Facb- $R^{+}$cell depletion on $N K$ cytotoxicity of PBMNC

\% Specific cytotoxicity $\left({ }^{51} \mathrm{Cr}\right.$ release) at different lymphocyte:target cell ratios

\begin{tabular}{lll}
\cline { 2 - 3 }$P B M N C$ & $60: 1$ & $30: 1$ \\
\hline Non-depleted & $20 \cdot 8 \pm 7 \cdot 2$ & $16 \cdot 4 \pm 6 \cdot 1$ \\
Facb- $\mathrm{R}^{+}$depleted & $20 \cdot 9 \pm 11 \cdot 4$ & $18 \cdot 1 \pm 9 \cdot 0$
\end{tabular}

Results are presented as the mean \pm standard deviation of five experiments. The spontaneous ${ }^{51} \mathrm{Cr}$ release from the target cells was $23 \cdot 3 \pm 1 \cdot 3 \%$.

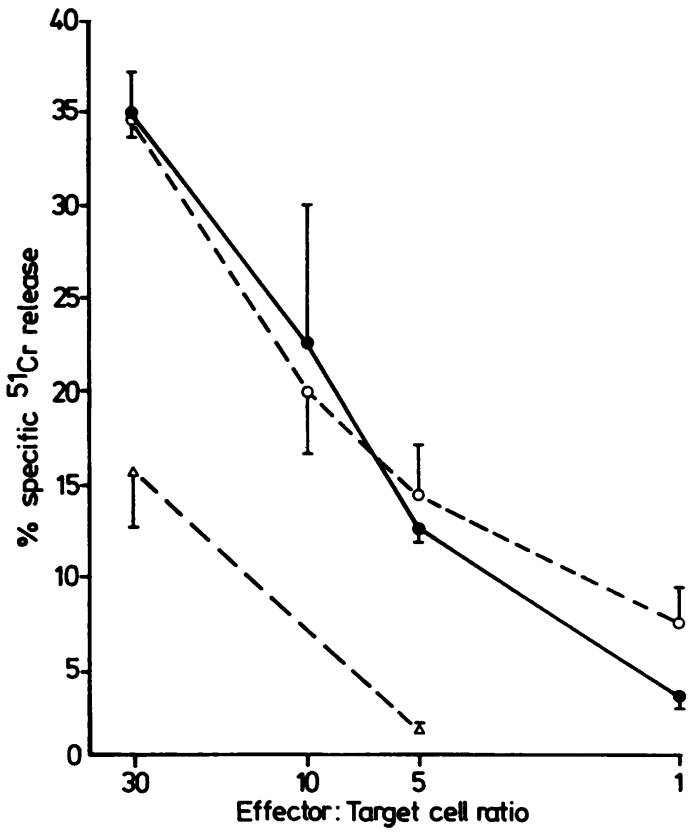

Fig. 2 Antibody-dependent cellular cytotoxicity of $P B M N C$ fractions at various effector : target cell ratios. Results are presented as $\%$ specific ${ }^{51} \mathrm{Cr}$ release (corrected for release in the absence of antibody). Data points represent the mean \pm standard deviation of seven experiments. $P B M N C ; O-O ;$ Facb $-R^{+}$depleted PBMNC: $\triangle--\triangle$ FcR $R^{+}$depleted PBMNC.

\section{Discussion}

Mononuclear cells expressing FcR have been shown to mediate a number of functions including natural and antibody-dependent cytotoxicity ${ }^{6-8}$ and both enhancing and suppressive effects on lymphocyte function. ${ }^{57910}$ Although forming part of the $\mathrm{FcR}^{+}$ population, Facb- $\mathbf{R}^{+}$cells do not exhibit cytotoxic activity. This supports the conclusion drawn from the surface phenotype analysis, namely, a lack of identity between Facb- $\mathrm{R}^{+}$cells and the $\mathrm{L}$ cell population described by Horwitz and coworkers. ${ }^{347}$ The lack of cytotoxic activity by Facb- $\mathrm{R}^{+}$cells is also consistent with the observations of elevated levels of these cells, ${ }^{2}$ but normal NK function ${ }^{14}$ and $\mathrm{ADCC}^{13}$ in rheumatoid peripheral blood.

Our results indicate a role for Facb- $\mathrm{R}^{+}$cells in certain lymphocyte responses involved in antibody synthesis but not others such as $T$ cell proliferation. The ability of Facb fragments to inhibit PWM-driven IgG synthesis might be due to the activation of a suppressor mechanism or to the blocking of a positive, accessory function of Facb- $\mathrm{R}^{+}$cells. These possibilities were investigated by depleting PBMNC of Facb- $\mathrm{R}^{+}$cells before culture. Removal of a suppressor population should result in enhanced IgG production, whereas loss of accessory cells would diminish antibody synthesis. Our results clearly indicate that Facb- $\mathrm{R}^{+}$cells are necessary for PWM-stimulated IgG production and that this function may be blocked by Facb fragments. The addition of Facb fragments to Facb- $\mathrm{R}^{+}$depleted cell cultures had no effect, supporting the assumption that their effect is mediated via Facb- $\mathbf{R}^{+}$cells. Depletion of Facb- $\mathbf{R}^{+}$cells did not result in a significant loss of monocytes as judged by staining for non-specific esterase. The 'accessory' function of Facb- $R^{+}$cells is consistent with the demonstration of class II MHC antigens (HLA-DR) on these cells ${ }^{1}$ a property shared by all antigenpresenting cell populations. ${ }^{15}$ Further experiments are in progress to investigate antigen-presenting functions of Facb- $R^{+}$cells using specific antigens. Our data on the functions of Facb- $\mathbf{R}^{+}$cells are similar but not identical to those described for $\mathrm{L}$ cells by Lobo. ${ }^{5}$ These include inhibition of immunoglobulin synthesis following treatment with immune complexes and enhancing effects on lymphocyte proliferation. Further studies are required to determine whether, under certain circumstances, human Facb- $\mathrm{R}^{+}$cells may be stimulated to exert a direct suppressive action, although some evidence for such an effect has recently been obtained in mice. ${ }^{16}$

Results from the present study do indeed show similarities to those obtained in mice where Facb- $\mathbf{R}^{+}$ cells were unaffected by delayed hypersensitivity reactions to oxazolone or to sheep erythrocytes but were elevated during the secondary antibody response to the latter antigen. ${ }^{16}$ This report also demonstrated that antigen-specific Facb fragments could dramatically suppress specific antibody production in vivo and that Facb- $\mathrm{R}^{+}$cells might therefore mediate IgG-dependent feedback inhibition of further antibody synthesis. Such feedback inhibition has been recognised for many years ${ }^{17}$ and has been considered to operate either via a direct blockade of B lymphocytes ${ }^{18}$ or by interfering with T-B cell 
interactions. ${ }^{19}$ The present study clearly shows that, although PWM-dependent IgG synthesis is markedly inhibited by Facb- $\mathrm{R}^{+}$cell depletion, mitogen-induced $T$ cell proliferation is virtually unaffected. This suggests that Facb- $\mathrm{R}^{+}$cells do not interact significantly with $\mathrm{T}$ lymphocytes, and, since Facb- $\mathrm{R}^{+}$cells do not have any characteristics of B lymphocytes, ${ }^{1}$ our studies might be taken to support Hoffman's concept of feedback inhibition of antibody production, namely, an effect on T-B cell co-operation. ${ }^{19}$

Although the precise mechanism whereby Facb- $\mathrm{R}^{+}$cells are involved in feedback inhibition remains to be elucidated, our results strongly suggest that rheumatoid PBMNC are significantly less sensitive to such regulation than healthy cells. This might be due to the increased numbers of Facb- $\mathrm{R}^{+}$cells in the rheumatoid samples. However, this increase is small (up to 5-fold) compared with the decreased sensitivity of RA cells to inhibition by Facb fragments (100-fold, Fig. 1). There is evidence that rheumatoid Facb- $\mathrm{R}^{+}$cells are in an activated state when isolated ex vivo (in preparation) and thus could be less susceptible to the effects of ligands added in vitro. Alternatively, some rheumatoid B cells might be inherently resistant to feedback suppression by $\operatorname{IgG}$ antibody. Such a selective immunoregulatory defect affecting an autoimmune response would lead to excessive antibody production with the likelihood of serious consequences, including immune complex deposition and subsequent inflammatory tissue damage.

This project was financed by a grant from the Arthritis and Rheumatism Council for Research. We also thank the Science and Engineering Research Council for the award of a CASE studentship to L.J.E. and Dr P W Bland, for his help with the ADCC assays.

\section{References}

1 Winrow V R, Eales L-J, Hall N D, Goulding N J, Hunneyball I M. Lymphocytes bearing Fcy receptors in rheumatoid arthritis. II. Phenotypic characterisation of mononuclear cells forming Facb rosettes in RA. Ann Rheum Dis 1985; 44: 2-7.

2 Hall N D, Winrow V R, Bacon P A. Lymphocytes bearing Fcy receptors in rheumatoid arthritis. I. An increased subpopulation of cells in rheumatoid arthritis detected with Facb rosettes. Ann Rheum Dis 1980; 39: 554-8.

3 Horwitz D A, Niaudet P, Greaves M F, Dorling J, Deteix P.
Surface markers and electron microscopy of human blood cells: a comparison with T and B lymphocytes. J Immunol 1978 121: 678-84.

4 Kay H D, Horwitz D A. Evidence by reactivity with hybridom $\frac{0}{5}$ antibodies for a probable myeloid origin of peripheral blood cells active in natural cytotoxicity and antibody-dependent cel ㅜㅡㄹ mediated cytotoxicity. J Clin Invest 1980; 66: 847-51.

5 Lobo P I. Characterisation of a non-T, non-B human lymphocyt (L cell) with use of monoclonal antibodies. Its regulatory role in B lymphocyte function. J Clin Invest 1981; 68: 431-8.

6 Wisløff F, Frøland S S, Michaelsen, T E. Antibody-dependent cytotoxicity mediated by human $\mathrm{Fc}$ receptor-bearing cells lacking markers for B- and T-lymphocytes. Int Arch Allergy App $\bar{L}$ Immunol 1974; 47: 139-54.

7 Horwitz D A, Garrett M A. Distinctive functional properties of human blood L lymphocytes: a comparison with $T$ lymphocyte 5 B lymphocytes and monocytes.J Immunol 1977; 118: 1712-21.

8 Ozer H, Strelkauskas A J, Callery R T, Schlossman S F. Th $\oplus$ functional dissection of human peripheral null cells with respectto antibody-dependent cellular cytotoxicity and natural killinge Eur J Immunol 1979; 9: 112-8.

9 Carvalho E M, Horwitz D A. Characterisation of a non-T, non- $\vec{B}$ human blood lymphocyte that mediates the enhancing effects of immune complexes on lymphocyte blastogenesis. J Immunof 1980; 124: 1656-61.

10 Caraux J, Klein B, Thierry C, Serrou B. Amplification of the polyclonal activation of human $\mathrm{T}$ cells. $\mathrm{I}$. Null cell products promote the polyclonal proliferation of $\mathrm{T}$ cells. Immunologu 1982; 45: 257-63.

11 Bøyum A. A one stage procedure for isolation of granulocytes and lymphocytes from human blood. Scand J Clin Lab Inves? 1968; 21: (Suppl 97): 77-89.

12 Pape G R, Moretta L, Troye M, Perlmann P. Natural cytotoxic ity of human Fcy receptor-positive T lymphocytes after surface modulation with immune complexes. Scand J Immunol 1979; 291-6.

13 Panayi G S, Corrigall V. Functional assay of cytotoxic lympho cytes involved in antibody-mediated cytotoxicity in normal anФ rheumatoid subjects. Ann Rheum Dis 1977; 36: 257-60.

14 Burmester G R, Kalden J R, Peter H H, Schedel I, Beck Pe Wittenborg A. Immunological and functional characteristics of peripheral blood and synovial fluid lymphocytes from patients. with rheumatoid arthritis. Scand J Immunol 1978; 7: 405-17.

15 Unanue E R, Beller D I, Lu C Y, Allen P M. Antigen presentation: comments on its regulation and mechanism. J Immunof 1984; 132: $1-5$.

16 Eales L-J, Hall N D, Hunneyball I M. Facb rosette-forming cel in mice: studies on their functional significance. Immunolog 1984; 52: 17-24.

17 Sinclair N R StC. Regulation of the immune response. I. Reduc tion in ability of specific antibody to inhibit long-lasting $\operatorname{Ig} Q$ immunological priming after removal of the Fc fragment. J Ex Med 1969; 129: 1183-201.

18 Kölsch E, Oberbarnscheidt J, Bruner K, Heuer J. The Fc recep tor: its role in the transmission of differentiation signals. Immunol Rev 1980; 49: 61-78.

19 Hoffman M K. Antibody regulates the co-operation of B celßs with helper cells. Immunol Rev 1980; 49: 79-91. 